DOI: https://doi.org/10.15407/techned2018.04 $: \underline{065}$

\title{
HIGH-VOLTAGE MULTIPHASE SEMICONDUCTOR CONVERTERS WITH REDUCED ENERGY ACCUMULATION FOR GAS-DISCHARGE INSTALLATIONS
}

Journal

Publisher

ISSN

Issue

Pages
Tekhnichna elektrodynamika

Institute of Electrodynamics National Academy of Science of Ukraine 1607-7970 (print), 2218-1903 (online)

No 4, 2018 (July/August)

$65-69$

\section{Authors}

\section{V.V. Martynov*, A.A. Shcherba**}

Institute of Electrodynamics National Academy of Sciences of Ukraine,

pr. Peremohy, 56, Kyiv, 03057, Ukraine,

e-mail: mart_v@ied.org.ua

* ORCID ID : http://orcid.org/0000-0003-2184-0394

** ORCID ID : http://orcid.org/0000-0002-0200-369X

\section{Abstract}

A new concept has been developed for constructing of the high-voltage multiphase semiconductor converters with reduced energy storage for gas-discharge installations. The concept is developed on the basis of the creation of parallel-connected synchronous symmetric non-phase semiconductor structures with a reduced accumulation of energy in the output circuits. This approach allows the creation of converters which realize without the use of energy-intensive filters both low level of output voltage ripples and non-oscillatory pulse current change at low multiplicity and a non-current pause during the impulse decrease of the load 
resistance. Using the structural-analytical transformation and simulation modeling, it was justified that the variety of structural schemes of such multiphase converters can be reduced to an equivalent single-phase scheme that greatly simplifies their modeling, analysis and design of necessary feedback devices, as well as the determination of stability regions and the required dynamics of the entire system. References 12, figures 6 .

Key words: semiconductor converter, voltage, current, pulse, non-phase semiconductor structures, symmetry, stabilization, gas discharge installation, nonstationary regimes.

Received: 05.03 .2018

Accepted: 26.03.2018

Published:

\section{References}

1. Kazimirov N.N., Loskutov G.A. Transient processes in the power source when the discharge in the welding gun goes out. Avtomaticheskaia svarka. 1983. No 11 (368). Pp. 41-43. (Rus)

2. Kruchinin A.M., Dolbilin E.V., Chursin A.Yu. Power sources of installations with concentrated streams of electricity. Elektrotekhnika. 1987. No 8. Pp. 36-39. (Rus)

3. Martynov V.V., Montgeran Yu.P., Mozharovsky A.G., Lebedev B.B., Smiitiukh G.E., Chaika N.V., Ivanov A.M. High-voltage power supply for electron-beam heating. Sovremennaia elektrometalurgiia

2010. No 2. Pp. 57-60. (Rus)

4. Tkachev L.G., Batov N.G. Wave processes in technological installations with electron beam heating. Elektrotekhnika. 1995. No 9. Pp. 39-41. (Rus)

5. Nazarenko O.K., Gurin O.A., Bolgov E.I. Features of current protection of power supplies for electron-beam welding. Avtomaticheskaia svarka. 2013. No 1. Pp. 3-6. (Rus)

6. Martynov V.V. Sources of power supply for electron beam and plasma technological 
equipment. Pratsi Instytutu Elektrodynamiku Natsionalnoi Akademii Nauk Ukrainy. 2004. No 3(9). Pp. 43-49. (Rus)

7. Martynov V.V., Rudenko Yu.V., Montgeran Yu.P. Investigation of the interaction of power transistor converters with arc, plasma and beam technological loads. Pratsi Instytutu Elektrodynamiku Natsionalnoi Akademii Nauk Ukrainy . 2010. No 25. Pp. 145-159. (Ukr)

8. Martynov V.V., Rudenko Yu.V. Load characteristics of an asymmetric inverter with magnetically bound choke. Vestnik Natsionalnogo Tekhnicheskogo Universiteta Kharkovskyi Politekhnicheskii Institut . 2017. Issue 27(1249). Pp. 234-237. (Rus)

9. Yurchenko A.I., Golovatsky V.A. Multi-phase impulse regulators of constant voltage. Elektron naia tekhnika $v$ avtomatike . 1978. Issue. 10. Pp. 107-113. (Rus)

10. R. Redl and N.O. Sokal, Current-mode control, five different types, used with the three basic classes of power converters: small-signal AC and large-signal DC characterization, stability requirements, and implementation of practical circuits. In Proc. IEEE PESC'85. Pp. 771-785 DOI:

https://doi.org/10.1109/PESC.1985.7071020

11. Dzhuri E. Pulse systems of automatic regulation. Moskva: Fizmatgiz, 1963. 456 p. (Rus)

12. Tsypkin Ya.Z. Theory of linear impulse systems. Moskva: Fizmatgiz, 1963. 968 p. (Rus) 